\title{
The Investigation of Some Physical, Physiological and Anthropometric Parameters of Visually Impaired and Non-impaired a National Male Judoka
}

\author{
Muhammet Hakan Mayda ${ }^{1}$, Onder Karakoc ${ }^{2}$, Mustafa Ozdal ${ }^{2}$ \\ ${ }^{1}$ Yasar Dogu Faculty of Sport Sciences, Physical Training and Sports Department, Ondokuz Mayıs University, Turkey \\ ${ }^{2}$ Physical Education and Sports Department, Gaziantep University, Turkey \\ Correspondence: Muhammet Hakan Mayda, Yasar Dogu Faculty of Sport Sciences, Physical Training and Sports \\ Department, Ondokuz Mayis University, Turkey.
}

Received: March 10, 2016

doi:10.11114/jets.v4i6.1444

\author{
Accepted: March 24, $2016 \quad$ Online Published: April 22, 2016 \\ URL: http://dx.doi.org/10.11114/jets.v4i6.1444
}

\begin{abstract}
It was pointed to analyze some physical, physiological and anthropometric parameters of visually impaired and non-impaired A National male judoka in this study. A total of 14 volunteer A National male judoka, of which 8 were visually impaired (age: $25.12 \pm 3.75$, disability status: 20-200) and 6 were not visually impaired (age: $21.50 \pm 1.51$ ), participated in this study. Statistical data was evaluated by using Independent Samples T-test in SPSS package program. There were no considerable difference between impaired and non-impaired judoka with respect to grip strength, vertical jump, 30-s sit-up, 30-s push-up, anaerobic power and auditory reaction test parameters among the physical and physiological tests. No significant difference between impaired and non-impaired judoka was detected with respect to body fat ratio, one of the anthropometric measurements performed. All in all, it was observed in national judoka investigated in this study that impairment variable didn't significantly affected physical, physiological and anthropometric parameter values $(\mathrm{p}>0.05)$. It is considered that vision factor doesn't have negatory impact on the physical performance grades because of the similarity of the elite judoka's training levels.
\end{abstract}

Keywords: judo, visually impaired, physical, physiological, anthropometric

\section{Introduction}

Judo sport is one of the sport subjects, which is able to be performed by impaired and non-impaired athletes, all over the world. Visually impaired are able to do judo sport for the aim of the rehabilitation. Self-discipline and respect develop in the individuals performing judo. It is one of the ways to gain self-confidence, balance, concentration, leadership skills, mental development and also physical fitness.

Judo is a tool for a discipline, a recreational or social activity, fitness program, and self-defense and fighting (Karakoc, 2014a). Judo, one of the Olympic sports, requires high performance with respect to technical, tactical and physical well-being (Little, 1991). Technical and tactical characteristics, that are many complex skills in high-severe intensity, are important for success in judo (Callister et al., 1991).

Physical durability, fitness and elevated grade of muscle strength further take an important function to be successful in international competitions (Franchini et al., 2011). The increase of $\mathrm{O} 2$ exchange at the cell level as a result of endurance trainings is an increase linked to the development of the cardiovascular system and this takes an important role in the judo competitions (Van Zant et al., 1993).

The maximal aerobic power can be defined as the maximal amount of oxygen which the organism can take from the atmosphere, carry to the tissues and use there. The muscle provides ATP renewal from anaerobic metabolism, in addition to oxidative mechanisms. Energy utilization in judo composes of ATP-CP system at $90 \%$ and aerobic system at 10\%. Many factors like aerobic and anaerobic powers, training level, age, gender and body composition affect the success (Fox et al., 1988; MacDougall et al., 1991).

An excess of adipose tissue in the body negatively affects performance for all sport branches including aerobic and anaerobic exercises. An athlete having a high percentage of fat in body weight shows less power, less explosive strength 
and endurance when compared to an athlete having a low percentage of fat. Because, the formation of unwanted excess weight together with high body fat ratio leads judoka's strength, agility and flexibility to reduce and to lose excessive energy. Hand grip strength can also be regarded as an indicator of the whole body (Imamoğlu et al., 2001).

It is very important for judoka to continue their ideal performances throughout the year. This requires a combination of many factors. Therefore, the features like aerobic capacity, power, speed, anaerobic power, flexibility, coordination and balance must be improved with particular trainings in judo, besides the tactical and technical exercises (Karakoc, 2014b).

While the factors affecting the reaction time positively are attention, motivation, doping, speed training, warming, education level, habits, alertness and intelligence, the ones affecting negatively are listed as alcohol, inadequate training, fatigue, age, gender, the type of stimulus, obesity and psychophysiological factors (Gunduz, 1998).

Individuals with visual impairment require more assistance in the psychological and physical progress. In the comparison of visually impaired and normal individuals, the physical and psychological development seems to be worse in visually impaired ones (Lieberman and McHugh, 2001). Sport and exercise should be performed to supply utilities to the life quality for impaired persons. However, people with disabilities don't have the facilities as sedentary persons.

The opinion is defended that the retardation in the development of the motor in visually impaired persons arises from the deficiency of knowledge, not the loss of ability, and they should act in an appropriate atmosphere supplied and require to be prompted to join in physical actions (Capps et al., 1996). But, it is required to supply high-grade motor achievement, and preserve and ensure dynamic and static equilibrium to provide effective achievement in sport areas. Arrangement in the circumstance of accordance in the branches needing motor capabilities is made to the persons who are deficient in motor capabilities in accordance with impairment levels (Erkmen et al., 2007).

The science is tried to be contributed by this study investigating visually impaired and visually non-impaired elite judoka at the physical, physiological and anthropometric manners.

\section{Materials and Methods}

It was pointed to analyze some physical, physiological and anthropometric factors of A National male visually impaired and non-impaired judoka. A total of 14 volunteer A National male judoka, of which 8 were visually impaired (age: $25.12 \pm 3.75$, disability status: $20-200$ ) and 6 were not visually impaired (age: $21.50 \pm 1.51$ ), participated in this study. Judoka joined to this study, which were visually disabled, had visual disability license at B3 level.

It was detected for the research groups if there was a heavy damage in the recent 6 months by inquiring via a survey prepared for the hearing disabled persons by sign language translators. A letter defining which they were voluntary and notified for the trials to be implemented in the research was served to the research groups and they signed these documents.

The research was performed in the gymnasium of Physical Education and Sports School in Gaziantep University. The experiments in the research were implemented according to common preparatory term exercise schedule of the athletes.

\subsection{Measurements Protocols}

\subsubsection{Height}

The stadiometer (SECA, Germany) showing $0.01 \mathrm{~m}$ level of sensitivity was used to measure height in accordance with the measuring methods (Zhu et al, 2015).

\subsubsection{Weight}

The subjects had naked feet and didn't wear shoe, only T-shirts and shorts were worn by them and an electronic measure (SECA, Germany) showing $0.1 \mathrm{~kg}$ level of sensitivity to measure the weights (Zhu et al, 2015).

\subsubsection{Hand Grip Strength Measurements}

The dynamometer (digital, Takei) was used to measure hand grip strength. The dynamometer was adjusted and calibrated in accordance with the hand and finger characteristics of the athletes while measuring each athlete. Repeats of the strength measurements were realized twice. When the other arm, which was not subjected to the measurement, didn't take any power, the measurements were realized. The value of better strength trial realized was registered in kilograms (Tamer, 2000).

\subsubsection{Sit-up Test}

In 30-sec sit-up performances of the athletes, hand chronometer with 1/1000 s level of sensitivity was employed. The athletes realized sit-up for $30 \mathrm{~s}$ with the initiation order until they could do afterwards they laid on their back, flexed 
knees, put the hands on neck and contacted their feet base on the base. During sit-up, the feet were kept to avoid the feet to remove from the ground. Whether the shoulders of the athletes contacted to the base were attentively checked during they laid on the base and their elbows contacted to their knees when they became straight. The number of sit-up performed in $30 \mathrm{~s}$ was registered to data paper (Ozer, 2001).

\subsubsection{Push-up Test}

Athletes laid on the base during their faces were looking the base, their feet were extended from the knee and forced their bodies up and down in stretched condition in the knee without contacting the base when the weight of the body was on the tips of the feet and arms. The number of push-up performed within $30 \mathrm{~s}$ was registered to data paper (Sevim, 1997).

In 30-sec push-up performances of the athletes, hand chronometer with 1/1000 s level of sensitivity was employed. The athletes performed push-up with the initiation order for $30 \mathrm{~s}$.

\subsubsection{Vertical Jumping Test and Anaerobic Power Measurements}

The measurements were realized by using vertical jumping board. The last point touched by the fingertips was marked while the feet were together, the body was at upright position and both of arms were extended upward. Then, the subject touched to the board by jumping upward with double feet in full force. The subject didn't step during jumping upward and bended the knees to 90 degrees.This process was repeated 3 times and the best result was recorded. Anaerobic power was calculated with the formula below, which was also defined by Fox et al., (1998), by using jumping distance and body weight (Tamer, 2000).

$$
\text { Anaerobic power }(\mathrm{kg} \cdot \mathrm{m} / \mathrm{s})=\sqrt{4.9} \times(\text { Body weight }) \times \sqrt{D}
$$

$\mathrm{D}=$ Vertically jumping distance

\subsubsection{Reaction Test}

Auditory reaction time measurements of the right and left hands were performed by 'Newtest Reaction Timer' instrument having 1/1000 s degree of precision. During measurements, the subjects were asked to concentrate on the test and were said to press the button with their forefingers together with the ready command within 3 seconds. 5 sample measurements were taken and these values were excluded from the evaluation in order to make the subjects familiar to the measurement technique. Then, the lowest and highest values among 5 measurements taken from the subjects were kept out of the evaluation and the mean of the remaining 3 measurements was recorded as the measurement score (milliseconds) of the subject (Tamer, 2000).

\subsubsection{Body Fat Percentage}

Holtain skinfold caliper applying $10 \mathrm{~g} / \mathrm{mm}^{2}$ pressure at every angle was employed to measure the skinfold. The measures got from the measurements of skinfold previously detected in suprailiac, abdomen, sub-scapular and triceps regions were employed to calculate the subjects' body fat percentages. All these were determined using Yuhasz equation. The right sides of all subjects were used to take measurements (Oddy et al, 2014).

\subsection{Data Analysis}

SPSS 16.0 software program was used to analyze data statistically. $95 \%$ confidence margin and significance grades at $\mathrm{p}$ $<0.05$ and $\mathrm{p}<0.01$ were used in evaluation of statistical data. Independent Samples T-Test was employed to analyze the differences between A National Team's athletes visually disabled and visually non-disabled because normality and homogeneously dispersion were seen among the measurements. 


\section{Results}

Table 1. Physical and Physiological Performance Table of Visually Impaired and Visually Non-Impaired National Judoka

\begin{tabular}{|c|c|c|c|c|c|}
\hline & Groups & $\mathrm{N}$ & Mean & Std. Deviation & $\mathrm{p}$ \\
\hline \multirow{2}{*}{ Age (years) } & Visually Imp. National & 8 & 25.12 & 3.76 & \multirow{2}{*}{0.108} \\
\hline & National & 6 & 21.50 & 1.52 & \\
\hline \multirow{2}{*}{ Height (cm) } & Visually Imp. National & 8 & 171.50 & 6.46 & \multirow{2}{*}{0.573} \\
\hline & National & 6 & 173.33 & 6.92 & \\
\hline \multirow{2}{*}{ Weight (kg) } & Visually Imp. National & 8 & 74.00 & 9.01 & \multirow{2}{*}{0.755} \\
\hline & National & 6 & 87.67 & 29.51 & \\
\hline \multirow{2}{*}{ Right hand grip strength $(\mathrm{kg})$} & Visually Imp. National & 8 & 40.47 & 7.63 & \multirow{2}{*}{0.181} \\
\hline & National & 6 & 47.07 & 8.75 & \\
\hline \multirow{2}{*}{ Left hand grip strength $(\mathrm{kg})$} & Visually Imp. National & 8 & 43.32 & 7.50 & \multirow{2}{*}{0.414} \\
\hline & National & 6 & 47.78 & 7.77 & \\
\hline \multirow{2}{*}{ Sit-up test (rep.) } & Visually Imp. National & 8 & 27.50 & 3.82 & \multirow{2}{*}{0.059} \\
\hline & National & 6 & 30.83 & 1.47 & \\
\hline \multirow{2}{*}{ Push-up test (rep.) } & Visually Imp. National & 8 & 40.00 & 4.47 & \multirow{2}{*}{0.755} \\
\hline & National & 6 & 41.83 & 9.39 & \\
\hline Anaerobic power (kg.m/sn) & Visually Imp. National & $\begin{array}{l}8 \\
6\end{array}$ & $\begin{array}{l}102.12 \\
112.55\end{array}$ & $\begin{array}{l}18.62 \\
28.20\end{array}$ & 0.573 \\
\hline \multirow{2}{*}{ Auditory reaction (ms) } & Visually Imp. National & 8 & 185.70 & 18.71 & \multirow{2}{*}{0.755} \\
\hline & National & 6 & 186.00 & 24.88 & \\
\hline \multirow{2}{*}{ Body fat percentage (\%) } & Visually Imp. National & 8 & 17.06 & 4.77 & \multirow{2}{*}{0.185} \\
\hline & National & 6 & 13.63 & 4.15 & \\
\hline
\end{tabular}

\section{Discussion and Conclusion}

It was subjected to analyze some physical, physiological and anthropometric parameters of visually impaired and non-impaired A National male judoka in this study.

For research groups, the height means were detected as $171.50 \pm 6.46 \mathrm{~cm}$ in visually impaired male judoka and 173.33 $\pm 6.92 \mathrm{~cm}$ in visually non-impaired male judoka. The weight means were observed as $74.00 \pm 9.01 \mathrm{~kg}$ in visually impaired male judoka and $87.67 \pm 29.51 \mathrm{~kg}$ in visually non-impaired male judoka.

As a result of the study evaluations, right hand grip power was detected as $40.47 \pm 7.63 \mathrm{~kg}$ in visually impaired male judoka and $47.07 \pm 8.75 \mathrm{~kg}$ in visually non-impaired male judoka. The mean left hand grip strength was detected as $43.32 \pm 7.50 \mathrm{~kg}$ in visually impaired male judoka and $47.78 \pm 7.77$ in visually non-impaired male judoka. Any statistically important relationship was not detected between our groups ( $p>0.05)$.

According to the evaluations of other parameters, 30-second sit-up test results were found to be $27.50 \pm 3.82$ rep. in visually impaired male judoka and $30.83 \pm 1.47$ rep. in visually non-impaired male judoka. 30 -second push-up test results were observed $40.00 \pm 4.47$ rep. in visually impaired male judoka and $41.83 \pm 9.39$ rep. in visually non-impaired male judoka. There was no significant correlation according to the evaluation results of 30 -second sit-up and push-up tests $(\mathrm{p}>0.05)$.

As a consequence of the evaluations realized, anaerobic power evaluation results were found to be $102.12 \pm 18.62 \mathrm{~kg} . \mathrm{m} / \mathrm{s}$ in visually impaired male judoka and $112.55 \pm 28.20 \mathrm{~kg} . \mathrm{m} / \mathrm{sin}$ visually non-impaired male judoka. Auditory reaction evaluation means were observed $185.70 \pm 18.71 \mathrm{~ms}$ in visually impaired male judoka and $186.00 \pm 24.88 \mathrm{~ms}$ in visually non-impaired male judoka. No statistically significant association was detected between two groups ( $>0.05$ ).

Researches in the literature propose that the trainings provide improvement. The power of the muscle is very crucial in the protection of physical performance. The protection of all motoric features can be provided by judo trainings.

It was observed in the study performed on elite and non-elite judoka by Franchini et al that the mean values of the right and left hand grip power of elite judoka were $51.01 \pm 10.0 \mathrm{~kg}$ and $49.01 \pm 10.0 \mathrm{~kg}$, respectively and the mean values of the right and left hand grip power of non-elite judoka were $42.01 \pm 11.0 \mathrm{~kg}$ and $40.01 \pm 10.0 \mathrm{~kg}$, respectively (Franchini et al., 2005).

It was detected in the study realized on physiological portrait of national judo team of Canada by Thomas et al that the mean values of the right and left hand grip power of judoka were $56.41 \pm 6.6 \mathrm{~kg}$ and $55.71 \pm 6.6 \mathrm{~kg}$, respectively (Thomas et al., 1989).

The mean values of the right and left hand grip power in young men were found as $52.01 \pm 8.3 \mathrm{~kg}$ and $50.61 \pm 8.5 \mathrm{~kg}$, respectively and the mean values the right and left hand grip power in adult men were $57.71 \pm 9.0 \mathrm{~kg}$ and $54.01 \pm 10.4 \mathrm{~kg}$, respectively, in the study performed by Little (Little, 1991).

Grip power is observed to be extremely influential in judo sport in a lot of researches. Grip power plays a very crucial 
role in judo exercises because there are heavy trainings and defiance related to keeping the dress. Severity, period and exercise type of the exercises in particularly preparatory duration influence the performance grades of the athletes.

It was observed in the research evaluating sit-up test value means in hearing impaired judoka that the pre-test mean value was $24.67 \pm 5.21$ rep. and the post-test mean value was $26.33 \pm 5.45$ rep. in the experimental group (Karakoc, 2014).

Yilmaz et al observed in the study investigating the effects of judo sport on some of the physical parameters of impaired students that the pre-test result was $9.84 \pm 3.51$ rep. and the post-test results was $15.82 \pm 4.67$ rep. in sit-up test $(\mathrm{p}<0.01)$. As a result of the study, they detected that a two-month basic judo training done by impaired students had positive effects on physical developments of impaired students (Yilmaz, 2013).

The difference between the study performed by Yilmaz et al and our study in terms of sit-up test value results is thought to arise from the state that the group in this study composed of elite and A National Team athletes.

It was detected in the study applied to judo team of Canada by Taylor and Brassard that the mean of push-up values of the team of men was $72 \pm 16$ (Taylor and Brassard, 1981). The mean values of push-up values of the team of men was observed as $56 \pm 8$ in the research performed by Krstulovic et al and appointed as young elite judoka's biomotor system (Krstulovic et al., 2006).

The means of pre-test and post-test values of the control group were detected as $21.33 \pm 9.35$ reps and $22.67 \pm 9.43$ reps, respectively and the means of pre-test and post-test values of the test group were found $24.73 \pm 9.50$ reps and $27.47 \pm$ 10.26 reps, respectively, in the research performed on hearing disabled athletes for $30 \mathrm{~s}$ push-up test ( $\mathrm{p}>0.05$ ) (Karakoc, 2014).

The cause of the dissimilarity between other researches and our research emerges from the situation that our research's athletes were elite and active athletes, were exposed to the dissimilar exercise schedules and had dissimilar disability situation when our study was compared to the other researches.

Stretchiness is the skill to act the joint or joint sets at broad ways. That's why, stretchiness has substantial emphasis both for the achievement and performance in sport and with respect to avoiding of damages (Doganand Zorba, 1991). An upper grade of stretchiness is required in judo to make many types of methods at plenty of broad angles and according to the primary movement.

It was found in a research performed on physiological portraits of athletes making combative arts that the average vertical jump test values were detected as $57.61 \pm 7.30 \mathrm{~cm}$ in MMA male athletes and $60.00 \pm 10$ in wrestlers (Gochioco et al., 2010).It was found in a research performed on male wrestlers who are the athletes making martial art that the average vertical jump values were observed as $49.00 \pm 5.00 \mathrm{~cm}$ in the test group and $48.00 \pm 4.00 \mathrm{~cm}$ in the control group (Akbal, 1998).

While anaerobic power was $124.00 \pm 16.46 \mathrm{~kg} . \mathrm{m} / \mathrm{s}$ in the university student male judoka in a study, anaerobic power was found as $132.00 \pm 20.3 \mathrm{~kg} \cdot \mathrm{m} / \mathrm{s}$ in our study. Anaerobic power value in our study seems to be better than the results of the university student male judoka. There was an important positive association at $\mathrm{p}<0.01$ level between anaerobic power and body fat percentage, body weight, right and left hand grip powers. Anaerobic power is expressed to be associated with certain parameters (Imamoglu et al., 2001).

No association between reaction time and any data (except between themselves) was found in the study conducted by Agaoglu et al. There was an association between themselves at $p<0.05$ level. Despite the fact that reaction times were found within the general distribution defined for the athletes in the study, they were detected weaker than the values defined for the athletes dealing with the sports like judo, wrestling and weightlifting. They reported that reaction time was one of the basic parameters for the success of judoka by considering the importance of reaction times in sudden moves and counterattacks (Agaoglu et al., 2001).

Body fat ratios were found as $8.9 \%$ in the team of Hungary, $12.3 \%$ in the team of Canada, $16.2 \%$ in the team of Japan, $13.7 \%$ in the team of Brazil and $8.3 \%$ in the team of North America in the research realized on men judo team of Brazil to assess anthropometric portraits and physical well-being of them (Franchini et al., 2007).

The athletes making judo for more than five years were categorized as group B and the athletes making judo for less than five years were categorized as group $\mathrm{A}$ in the research realized on anthropometric portraits of the body in accordance with the grades of judoka in fitness evaluation which was particular to judo. The mean body fat ratio values were detected as $11.9 \%$ and $13.8 \%$ for the groups A and B, respectively (Katralli and Goudar, 2012). In another study, sharp reductions in the measures of body weight, body fat percentage (BFP), body fat (BF) and lean body mass (LBM) of the experimental group were acquired thereafter 8-week submaximal aerobic training exposed to young male persons (Daglioglu, 2013). 
The opinion that training is efficacious in the improvement of motor capabilities in disabled persons is crucial with respect to presenting similarity with our study is specified in many researches in the literature.

On the whole, our study shows parallelism to many other studies when it is evaluated in terms of physical and physiological parameters between visually impaired and visually non-impaired judokas. It is considered that vision factor has no negative effect on the grades of physical performance because of the quite similarity of the elite judoka's exercise grades.

\section{References}

Agaoglu, S. A., Imamoglu, O., Kishali, N. F., \& Cebi, M. (2001). Journal of Physical Education and Sport Sciences, 1(3).

Akbal, M. (1998). Doctoral dissertation, SelcukUniversitesiSaglikBilimleriEnstitusu.

Callister, R., Callister, R. J., Staron, R. S., Fleck, S. J., Tesch, P., \& Dudley, G. A. (1991). Physiologicalcharacteristics of elite judo athletes. International Journal of Sports Medicine, 12(2), 196-203. http://dx.doi.org/10.1055/s-2007-1024667

Capps, L., Sigman, M., Sena, R., Heoker, B., \& Whalen, C. (1996). Fear, anxiety and perceived control in children of agoraphobic parents. Journal of Child Psychology and Psychiatry, 37(4), 445-452. http://dx.doi.org/10.1111/j.1469-7610.1996.tb01425.x

Daglioglu, O. (2013). The effect of 8-week submaximal aerobic exercise on cardiovascular parameters and body composition in young men. International Journal of Academic Research, 5(4).

Dogan, A. A., \& Zorba, E. (1991). Esnekligin Gelistirilmesinde Kullanilan Farkli Esnetme Tekniklerinin Etkinligi. HUEgitimFakultesiSporBilimleriDergisi, 2(4), 41-48.

Erkmen, N., Suveren, S., Goktepe, A. S., \& Yazicioglu, K. (2007). The Comparison of Balance Performance of the Athletes Who Are in Different Branches. Spormetre Physical Education and Sport Science Journal, 3-115. http://dx.doi.org/10.1501/sporm_0000000080

Fox, E. L., Bowers, R. W., \& Foss, M. F. (1988). The Physiological Basis of Physical Education and Athletes, Sounders College publishing 4 edit USA.

Franchini, E., Del Vecchio, F. B., Matsushigue, K. A., \& Artioli, G. G. (2011). Physiological profiles of elite judo athletes. Sports Medicine, 41(2), 147-166. http://dx.doi.org/10.2165/11538580-000000000-00000

Franchini, E., Nunes, A. V., Moraes, J. M., \& Del Vecchio, F. B. (2007). Physical fitness and anthropometrical profile of the Brazilian male judo team. Journal of Physiological Anthropology,26(2), 59-67. http://dx.doi.org/10.2114/jpa2.26.59

Franchini, E., Takito, M. Y., Kiss, M., \& Strerkowicz, S. (2005). Physical fitness and anthropometrical differences between elite and non-elite judo players. Biology of Sport, 22(4), 315.

Gochioco, M., Schick, E., Dabbs, N., Khamoui, A., Tran, T., Brown, L., Cobum, J., \& Beam, W. (2010). Physiological profile of amateur mixed martial artists. Journal Medicine \& Science in Sports \& Exercise, 42(5), 837-838. http://dx.doi.org/10.1249/01.mss.0000386626.85052.ea

Gunduz, N. (1998). Antrenman Bilgisi. Saray Medikal Yayıncilik, Kanyilmaz Matbaasi, Ankara, 193-194.

http://dx.doi.org/10.7813/2075-4124.2013/5-4/a.29

Imamoglu, O., Agaoglu, S. A., Kishali, N. F., \& Cebi, M. (2001). Relationships among Aerobic Power, Anaerobic Power, Body Fat Percent, Hand Grip and Vital Capacity in National Male Judos. Journal of Physical Education and Sport Sciences, 1(3).

Karakoc, O. (2014a). Judo Ogreniyorum. SporYayinevi.

Karakoc, O. (2014b). Işitme Engelli Judocularda Sekiz Haftalık Denge VeKoordinasyon Antrenmanlarının Performans Uzerine Etkileri. Yayınlanmıs Doktora Tezi. Firat Universitesi, Saglik Bilimleri Enstitusu Beden Egitimive Spor Anabilim Dalı.

Katralli, J., \& Goudar, S. (2012). Anthropometric profile and special judo fitness levels of Indian judo players. Asian Journal of Sports Medicine, 3(2), 113. http://dx.doi.org/10.5812/asjsm.34710

Krstulovic, S., Zuvela, F., \& Katic, R. (2006). Biomotor systems in elite junior judoists. Collegium Antropologicum, 30(4), 845-851.

Lieberman, L., \& McHugh, E. (2001). Health-related fitness of children who are visually impaired. Journal of Visual 
Impairment \& Blindness, 95(05).

Little, N. G. (1991). Physical performance attributes of junior and senior women, juvenile, junior, and senior men judokas. The Journal of Sports Medicine and Physical Fitness, 31(4), 510-520.

MacDougall, J. D., Wenger, H. A., \& Green, H. J. (Eds.). (1991). Physiological testing of the high-performance athlete. Champaign, Ill.: Human Kinetics Books. http://dx.doi.org/10.1249/00005768-199302000-00027

Oddy, W. H., Mori, T. A., Huang, R. C., Marsh, J. A., Pennell, C. E., Chivers, P. T., Hands, B. P., Jacoby, P., Rzehak, P., Koletzko, B. V., \& Beilin, L. J. (2014). Early infant feeding and adiposity risk: from infancy to adulthood. Annals of Nutrition and Metabolism, 64(3-4), 262-270. http://dx.doi.org/10.1159/000365031

Özer, K. (2001). Fiziksel Uygunluk. Ankara: Nobel Yayınlar1.

Sevim, Y. (1997). Antrenman Bilgisi, Tutibay Ltd. Şti. Ankara.

Tamer, K. (2000). Sporda Fiziksel-Fizyolojik Performansin Olçculmesive Degerlendirilmesi. BagırganYayinevi, Ankara, $36,48-49$.

Taylor, A. W., \& Brassard, L. (1981). A physiological profile of the Canadian judo team. The Journal of Sports Medicine and Physical Fitness, 21(2), 160.

Thomas, S. G., Cox, M. H., LeGal, Y. M., Verde, T. J., \& Smith, H. K. (1989). Physiological profiles of the Canadian National Judo Team. Canadian journal of sport sciences: Journal Canadien des Sciences du Sport, 14(3), 142-147.

VanZant, R. S., \& Kuzma, S. H. (1993). Effect of Community Based Exercise and Education on Individual Fitness in a Corporate Setting. Research Quarterly for Exercise and Sport, 64(Suppl), 46-47.

Yılmaz, S. (2013). Judo Sporunun Görme Engelli Oğrenciler Uzerine Etkisinin Bazi Parametreler Acisindan İncelenmesi. SporBilimleriDergisi, 3.

Zhu, Y., Hernandez, L. M., Dong, Y., Himes, J. H., Hirschfeld, S., \& Forman, M. R. (2015). Longer breastfeeding duration reduces the positive relationships among gestational weight gain, birth weight and childhood anthropometrics. Journal of Epidemiology and Community Health, 69(7), 632-638. http://dx.doi.org/10.1136/jech-2014-204794

This work is licensed under a Creative Commons Attribution 3.0 License. 